\title{
Simultaneous determination of in situ vertical transitions of color, pore-water metals, and visualization of infaunal activity in marine sediments
}

\author{
Lorna R. Teal,a,b,* Ruth Parker, ${ }^{\mathrm{b}}$ Gary Fones, ${ }^{\mathrm{c}}$ and Martin Solan ${ }^{\mathrm{a}}$ \\ a Oceanlab, University of Aberdeen, Newburgh, Aberdeenshire, United Kingdom \\ b Centre for Environment, Fisheries and Aquaculture Science, Lowestoft, Suffolk, United Kingdom \\ c School of Earth and Environmental Sciences, University of Portsmouth, Portsmouth, United Kingdom
}

\begin{abstract}
The vertical color transition from brown to gray-green in marine sediments is linked to the Fe redox boundary and is commonly used as a proxy for biogeochemical state. We combine time-lapse sediment profile imaging with diffusive gradient thin (DGT) gels to obtain simultaneous in situ measurements of sediment color profiles, porewater Fe and Mn profiles, and qualitative estimates of faunal activity at the Oyster Ground and North Dogger (North Sea). Analysis of Fe and Mn profiles using generalized additive modeling reveals that high variability between profiles within the sites makes it difficult to determine any intersite differences in trace metal behavior. At the Oyster Ground, the depth of sediment color transition $(4.78 \pm 0.76 \mathrm{~cm})$ was not significantly different from the Fe redox boundary $(7.67 \pm 4.04 \mathrm{~cm})$. At the North Dogger, there was a significant discrepancy between the depth of the sediment color transition $(2.86 \pm 0.78 \mathrm{~cm})$ and the Fe redox boundary $(10.17 \pm 1.04 \mathrm{~cm})$, which most likely results from high sulfate reduction rates at the North Dogger, leading to complexation of reduced iron to a form not available to the DGT technique. The differences in the coupling of sediment color and the Fe redox boundary between stations is likely to be related to variations in recent infaunal bioturbation activity, rather than variations in sediment source or fundamental differences in bulk sediment chemistry. Our results highlight the importance of the infaunal community in mediating $\mathrm{Fe}$ and $\mathrm{Mn}$ cycles, which are key pathways in the degradation of organic matter, and suggest that descriptions of bulk chemistry alone may be insufficient to understand the dynamics of biogeochemical cycling.
\end{abstract}

A substantial proportion $(\leq 50 \%)$ of pelagic primary production reaches the seabed in continental margin environments (Jørgensen 1983), where it is rapidly subducted by infaunal invertebrates (Witte et al. 2003) and mineralized close to the sediment-water interface. Although the vertical extent over which decomposition in the sediment can take place can be profoundly influenced by the transfer of organic material to depth by infaunal bioturbation (Josefson et al. 2002), the degradation of such labile organic material is driven largely by the bacterial community and the availability of electron acceptors (in order of decreasing energy yield, $\mathrm{O}_{2}, \mathrm{NO}_{3}^{-}, \mathrm{Mn}$ and $\mathrm{Fe}$ oxides, $\mathrm{SO}_{4}^{2-}$, and $\mathrm{CO}_{2} ;$ Aller 1982). The sequential utilization of these electron acceptors leads to the wellknown vertical stratification of decomposition reactions in the sediment (Fenchel 1969) that regulate the magnitude and direction of benthic nutrient fluxes, which, in turn, are vital for primary productivity (Johnson et al. 1999).

Reduction of iron and manganese oxides, in contrast to other reduction processes, uses solid rather than dissolved electron acceptors. The most reactive metal oxides are generally poorly crystalline, amorphous phases (Burdige et al. 1992), which are often found as coatings on inorganic or biogenic particles. The color of marine sediment particles generally varies between light brown through gray to almost black, largely reflecting differences in the chemical speciation of iron and sulfur. In oxidized sediments, $\mathrm{Fe}$ forms $\mathrm{FeOOH}$, which is highly insoluble and gives the sediment a red-brown coloration, whereas, in reduced

\footnotetext{
*Corresponding author: 1.teal@abdn.ac.uk
}

sediments, Fe becomes highly soluble and, in the presence of sulfate reduction, forms iron monosulfides $(\mathrm{FeS})$, which have a characteristic olive-black color (Fenchel 1969; Lyle 1983; Bull and Williamson 2001). The relative expression of these two phases therefore provides the basis for a qualitative relationship between sediment color and redox state, such that images of the sediment profile have been routinely used (Rhoads and Cande 1971; Grizzle and Penniman 1991; Diaz and Cutter 2001) as a proxy of the biogeochemical state of the sediment; it is assumed that depth of the color transition reflects the Fe redox boundary which, in turn, is associated with the depth to which the sediment is most frequently mixed by infaunal invertebrates (Rhoads and Germano 1982) or the degree to which the sediment has been exposed to changes in oxygen (Diaz and Cutter 2001; Shchukarev et al. 2007). Although the connectivity between sediment color and $\mathrm{Fe}$ redox state may be considered intuitive, the validity of these assumptions within the context of studies using sediment profile imaging (SPI) has received little attention (exceptions include Rosenberg et al. 2001; Diaz and Trefry 2006). The link between sediment coloration, infaunal activity, and biogeochemical processes, although remaining vague (Teal et al. 2008), continues to be an important means of assessing sediment dynamics and, in turn, benthic habitat quality.

Because of the particulate nature of $\mathrm{Mn}$ and Fe oxides, bioturbation and other bulk transport mechanisms are particularly important regulators of $\mathrm{Mn}$ and $\mathrm{Fe}$ reduction (Thamdrup et al. 1994), yet they are seldom measured simultaneously. As Fe is also the key element responsible 
for sediment coloration, the ability to simultaneously measure vertical pore-water profiles of $\mathrm{Fe}$ and $\mathrm{Mn}$ alongside infaunal activity and sediment color profiles would provide a more comprehensive understanding of what drives trace metal cycling. Recent methods that have been used to elucidate metal-sediment interactions include the gel probe techniques diffusive equilibration in thin films (DET) and diffusive gradients in thin films (DGT) (Davison et al. 2000; Fones et al. 2004). These enable profiles of trace metals, including $\mathrm{Fe}$ and $\mathrm{Mn}$, to be obtained in situ at much higher resolution (millimeter scale) than previous techniques (centimeter scale) such as porewater recovery from coring (Ciceri et al. 1992). Interpretation of such pore-water profiles, however, can be difficult when the horizontal layering of biogeochemical processes is structured by infaunal activity, which tends to promote a spatially complex redox environment (Fones et al. 2004) replete with oscillating oxic, suboxic, and anoxic microniches (Forster and Graf 1992; Aller 1994).

Here we combine time-lapse sediment profile imaging ( $\mathrm{t}$ SPI) with DGT technology to visualize in situ faunal activity (particle bioturbation) and determine the relationship between sediment color and pore-water metal profiles (geochemical profiles) for two ecologically contrasting stations in the North Sea. Our objectives are (1) to improve the understanding of the link between sediment color and Fe redox processes, (2) to assess spatial heterogeneity of sediment processes within and between stations using appropriate statistical models that explicitly recognize nonlinearity of profile relationships, and (3) to gain a better understanding of sediment trace metal cycling.

\section{Methods}

The diffusive gel and resin gel for the DGT gels were prepared following standard procedures (Davison et al. 2000) by DGT Research (procedural manual available from www.dgtresearch.com). The diffusive gel used was an agarose-polyacrylamide hydrogel comprising 15\% acrylamide (Merck) and 0.3\% agarose-derived cross-linker (DGT Research). The resin gel binding layer consisted of a cation-exchange resin (Chelex-100), which has a bead size of $100 \mu \mathrm{m}$ impregnated in a thin gel (0.4-mm thickness). The resin gel was covered by the diffusive gel $(0.6-\mathrm{mm}$ thickness) and a $0.45-\mu \mathrm{m}$ pore size Whatman Millipore cellulose acetate filter membrane $(0.13-\mathrm{mm}$ thickness). The DGT gels were made up before use in a dust-free environment (laminar flow cabinet) and stored in sealed Ziplok ${ }^{\circledR}$ plastic bags at $4{ }^{\circ} \mathrm{C} \pm 1{ }^{\circ} \mathrm{C}$ before deployment.

A t-SPI (Rhoads and Cande 1971; Solan and Kennedy 2002) camera was used for sediment imaging and in situ deployment of DGT gels. The gel-SPI (g-SPI) used a Kodak Professional DCS Pro $14 \mathrm{n}$ digital camera $(3000 \times$ $4500=13.5$ megapixels) set to an exposure of $1 / 60$, an aperture $\mathrm{f}=4$, and a film speed equivalent to ISO 200. The visible area of the images is $18 \times 27 \mathrm{~cm}\left(486 \mathrm{~cm}^{2}\right)$ but the $\mathrm{g}$ SPI prism faceplate was modified to hold three DGT gel strips $(20.5 \mathrm{~cm} \times 2 \mathrm{~cm} \times 0.2 \mathrm{~cm})$ within the field of view. The gel strip sandwiches (filter-resin gel-diffusive gelfilter) were placed into recesses on the SPI faceplate using nitrile gloves and were held in place by a clear acrylic holding plate (1-mm thick), held in position with 2-mmdiameter nylon screws (to prevent metal contamination of the gels). A maximum area $19.5 \mathrm{~cm} \times 1 \mathrm{~cm}$ of gel is exposed to the sediment during deployment, depending on SPI penetration and therefore gel exposure to the sediment.

The g-SPI was deployed using fixed moorings at two locations in the North Sea (Oyster Ground: $54.41^{\circ} \mathrm{N}$, $4.04^{\circ} \mathrm{W}$, water depth $46.7 \mathrm{~m}$; North Dogger: $55.68^{\circ} \mathrm{N}$, $2.28^{\circ} \mathrm{W}$; water depth $83.1 \mathrm{~m}$ ) in May 2007. At each location, images were taken at 5-min intervals over a period of $31 \mathrm{~h}$ (=372 images per deployment). As faunal behavior is context dependent because it is affected by abiotic variables such as the tidal (Solan and Kennedy 2002) and day-night cycle (Last 2003), the length of the deployment incorporates and integrates these cycles in full.

On recovery of the g-SPI, gels were rinsed with Milli-Q water to wash off any sediment and prevent further accumulation of trace metals. The gels were removed from the faceplate and stored in sealed plastic bags at $4{ }^{\circ} \mathrm{C} \pm 1{ }^{\circ} \mathrm{C}$ until analysis. The position of each DGT gel in relation to the sediment-water interface was determined using the final image of each time-lapse sequence.

To characterize the indicative infaunal communities present at each station, macrofauna were identified from the returns of four NIOZ cores $(\varnothing 30 \mathrm{~cm}$, sieved on a $1-\mathrm{mm}$ mesh) taken from within a 50-m radius around the camera. Fauna were stored in a $4 \%$ formaldehyde-seawater solution and, with the exception of the polychaetes (family), were identified to species level. Sediment analysis (for porosity, chlorophyll $a$, carbon content, particle size analysis) was carried out on the same cores.

Image analysis-The vertical color transition (from brown to olive green or black) in the sediment profile images was delineated using a custom-made, semiautomated macro (Solan et al. 2004) within ImageJ (version 1.38), a Java-based public domain program developed at the U.S. National Institutes of Health (available at http:// rsb.info.nih.gov/ij/index.html). The macro sequentially opens each image and converts it to an 8-bit (gray scale) tagged image file format. The user traces the sedimentwater interface with the segmented line tool, which serves as the upper limit of the region of interest. The lower limit of the region of interest is determined by using the most appropriate threshold level that distinguishes the highly reflective oxidized sediment from the underlying (low reflectance) reduced sediment. The color transition depth is taken to be the mean vertical distance of the sediment with gray-scale shades above the user-defined threshold value. As the field of view of the image is obstructed by the gels, each visible section was analyzed separately and averaged to provide a mean $(n=4)$ color transition depth for each station.

DGT analysis-All DGT sample preparation was undertaken in a laminar flow cabinet (BassAire-Class100). The top membrane and diffusive gel layer were discarded and the resin gel layer was sliced at 2-mm resolution using a Teflon-coated stainless steel razor blade. Each gel slice was 
eluted with $2 \mathrm{~mol} \mathrm{~L}-1 \mathrm{HNO}_{3}(100 \mu \mathrm{L})$ for $24 \mathrm{~h}$ and then diluted (75- $\mu \mathrm{L}$ sample : $\left.925 \mu \mathrm{L}, 2 \mathrm{~mol} \mathrm{~L}-1 \mathrm{HNO}_{3}\right)$. $\mathrm{HNO}_{3}$ $\left(2 \mathrm{~mol} \mathrm{~L}^{-1}\right)$ releases $80 \%( \pm 4 \%)$ of the metal bound to the Chelex (Zhang et al. 1995). The solutions were analyzed for two trace metals $(\mathrm{Fe}, \mathrm{Mn})$ using an Agilent Technologies 7500ce inductively coupled plasma-mass spectrometer (ICP-MS). The ICP-MS has an octopole reaction system to remove spectral interferences. Fe was analyzed in reaction mode $\left(\mathrm{H}_{2}\right)$, and $\mathrm{Mn}$ in collision mode $(\mathrm{He})$ to remove all the polyatomic spectral interferences. The ICPMS was calibrated every day before the analysis of samples using dilutions (0-200 $\left.\mu \mathrm{g} \mathrm{kg}^{-1}\right)$ of a mixed stock standard $(100 \mathrm{mg} \mathrm{kg}-1)$. An internal standard of $\mathrm{Rh}^{103}\left(50 \mu \mathrm{g} \mathrm{kg}^{-1}\right)$ was used to check the drift of the machine during the day and a certified reference material (SLRS-4) was used to check the calibrations and recovery of the ICP-MS.

The measured concentrations, $C_{\mathrm{g}}\left(\mu \mathrm{g} \mathrm{kg}^{-1}\right)$, of the DGT gel solutions were converted to molar concentrations and used to calculate the mass, $M(\mathrm{nmol} \mathrm{cm}-2)$, accumulated in the resin layer of each gel strip:

$$
M=\left(C_{\mathrm{g}}[v+V] / 0.8 A\right) / x
$$

where $v$ is the volume of gel $(\mathrm{mL}), V$ the extractant volume $(\mathrm{mL})$, and $x$ the atomic mass of the element in question. Knowing the time of gel deployment, $t$ (s), allowed calculation of the time-averaged flux $F\left(\mathrm{nmol} \mathrm{cm}^{-2} \mathrm{~s}^{-1}\right)$ of metal from the pore waters to the resin strip:

$$
F=M /(t \times A)
$$

where $A$ is the area of exposed gel $\left(\mathrm{cm}^{2}\right)$.

Statistical analysis-As differences in the shape of replicate profiles and the depth of flux peaks are of interest, rather than the absolute flux values, in contrast to previous qualitative methods (Lesven et al. 2008), we used general additive modeling (GAM, Wood 2006) to quantitatively compare replicate trace metal profiles. GAMs use smoothing curves to model nonlinear relationships between the response variable ( $\mathrm{Fe}$ or $\mathrm{Mn}$ flux) and the explanatory variable (Depth). The GAM smoother imposes a smoothness that trades off goodness of fit against the interpolation line (specified by the particular polynomial being fit) that summarizes the dependence of $y$ on $x$. This process maximizes the quality of the prediction and avoids models that overfit the data (i.e., prevents application of unnecessary complex models). Further details of the GAM fitting process are given in Wood (2006).

Following Wood (2006), thin plate smoothing splines were used to model the nonlinearity and the smoothing parameter estimation (degrees of freedom) was optimized using a generalized cross-validation procedure.

To test the degree of spatial heterogeneity in metal fluxdepth relationships, the flux-depth patterns were compared across station and within station replicate profiles using nested models. In this way it was possible to test whether all replicate profiles had the same flux-depth pattern, whether there was a station-dependent pattern, or whether the pattern was replicate specific. The following nested models were applied:

$$
\begin{aligned}
\operatorname{Flux}(\mathrm{Fe} \text { or } \mathrm{Mn})= & a+s(\text { Depth })+\text { factor }(I D)+\varepsilon \\
\operatorname{Flux}(\mathrm{Fe} \text { or } \mathrm{Mn})= & a+s(\text { Depth }): \text { OG } \\
& +s(\text { Depth }): N D+\text { factor }(I D) \\
& +\varepsilon
\end{aligned}
$$

$$
\begin{aligned}
\operatorname{Flux}(\mathrm{Fe} \text { or } \mathrm{Mn})= & a+s(\text { Depth }): P_{1}+s(\text { Depth }): P_{2} \\
& +s(\text { Depth }): P_{3}+s(\text { Depth }): P_{4} \\
& +s(\text { Depth }): P_{5} \\
& +s(\text { Depth }): P_{6}+\text { factor }(\text { ID })+\varepsilon(M 3)
\end{aligned}
$$

In Eq. M1, the same smoothing curve is fitted to all profiles $(s[$ Depth $])$. In Eq. M2 two separate smoothers were fitted to the profiles from each of the two stations, where the notation $s$ (Depth): OG identifies the smoother fitted to the Oyster Ground profiles and $s($ Depth $): N D$ identifies the smoother fitted to the profiles from the North Dogger. In Eq. M3 six smoothers were fitted, allowing each individual profile (denoted by $P_{1}-P_{6}$ ) to have its own smoother. Profile identity (ID) was added as a nominal explanatory variable (factor $[I D]$ ) in all models to account for differences in absolute flux values between replicates. From the three alternative models, the optimal model was selected using Akaike information criteria (AIC) and validated by visual comparison of residual plots. Where heterogeneity of variance was present, a variancecovariate structure (see table 5.1 in Pinheiro and Bates 2000) was incorporated (=generalized additive mixed modeling) and the appropriate variance structure was determined using $\mathrm{AIC}$ and visual comparison of residual plots.

A second analysis was performed to investigate the coupling of $\mathrm{Fe}$ and $\mathrm{Mn}$ at each site. Plotting $\mathrm{Mn}$ flux against $\mathrm{Fe}$ flux reveals a broken-line relationship. As trace metal cycling theory suggests that the Mn reduction zone can be separated from the Fe reduction zone using the break point visible in the plots, we performed a segmented regression (Muggeo 2003a) on Mn flux as a function of $\mathrm{Fe}$ flux to determine the break point, which was then back calculated to a depth in the sediment.

All analyses were performed using packages "mgcv" (Wood 2009) and "nlme" (Pinheiro et al. 2006) and the library "segmented" (Muggeo 2003b) in the "R" statistical and programming environment (v2.6; R Development Core Team 2005).

\section{Results}

Sediment profile images-The two sampling stations show similar characteristics overall (Table 1) but examination of the sediment profile images suggests that different faunal activity levels govern the sediment color at each location (Fig. 1A,B). Images from the Oyster Ground show a reddish-brown surficial sediment and a very gradual color change toward gray with depth (Fig. 1A). At the North Dogger, however, there is a more distinct boundary between the reddish-brown sediment layer and underlying 
Table 1. Summary of environmental, sediment, and faunal characteristics for the Oyster Ground and North Dogger at the time of sampling. Sediment porosity and chlorophyll $a$ are presented as the mean ( $\pm \mathrm{SD}, n=3$ in both cases) of the top $1 \mathrm{~cm}$. Carbon content, \% sand, and \% silt: clay represent the mean ( $\pm \mathrm{SD}, n=4$ in both cases) of the uppermost $5 \mathrm{~cm}$ of sediment. Faunal abundance, biomass, and species richness are the means $( \pm \mathrm{SD}, n=4$ in all cases) within each station.

\begin{tabular}{|c|c|c|}
\hline & Oyster Ground & North Dogger \\
\hline Depth (m) & 46.7 & 83.1 \\
\hline Bottom temperature $\left({ }^{\circ} \mathrm{C}\right)$ & 8.21 & 7.65 \\
\hline Porosity $(\%)$ & $0.61 \pm 0.05$ & $0.67 \pm 0.06$ \\
\hline Chlorophyll $a\left(\mathrm{mg} \mathrm{m}^{-2}\right)$ & $26.43 \pm 17.90$ & $44.47 \pm 38.66$ \\
\hline Carbon $\left(\mathrm{g} \mathrm{m}^{-3}\right)$ & $3051 \pm 577$ & $5195 \pm 1041$ \\
\hline$\%$ sand & $84.6 \pm 1.6$ & $75.3 \pm 2.0$ \\
\hline$\%$ silt : clay & $15.4 \pm 1.6$ & $24.7 \pm 2.0$ \\
\hline Abundance (individuals $\mathrm{m}^{-2}$ ) & $1370 \pm 370$ & $200 \pm 20$ \\
\hline Biomass (wet weight, $\mathrm{g} \mathrm{m}^{-2}$ ) & $180 \pm 160$ & $20 \pm 7$ \\
\hline Species richness & $13 \pm 2$ & $12 \pm 1$ \\
\hline
\end{tabular}

gray sediment mottled with dark patches (Fig. 1B). The color transition depth measured from the final image of the time-lapse sequence was deeper at the Oyster Ground (4.78 $\pm 0.76 \mathrm{~cm}, n=4)$ than at the North Dogger $(2.86 \pm$ $0.78 \mathrm{~cm}, n=4)$, indicating a deeper Fe redox boundary at the Oyster Ground (Fig. 1A,B). The gradual color change and lack of distinct color boundary at the Oyster Ground also provides anecdotal evidence that biological or physical processes hinder the development of distinct horizontal biogeochemical zones.

The t-SPI sequences show evidence of infaunal activity at both the Oyster Ground (see Sequence 1 in the Web Appendix, www.aslo.org/lo/toc/vol_54/issue_5/1801a.html) and North Dogger (see Sequence 2 in the Web Appendix), but the relative amount of sediment reworking contrasted markedly between the two locations. At the Oyster Ground, several individuals of an echinoid, most likely Brissopsis lyrifera (Table 2), were particularly active throughout the deployment and continuously redistributed the uppermost portions of the sediment profile. In contrast, at the North Dogger, there was less evidence of any significant sediment redistribution but there was an abundance of tubes (extending $\sim 2 \mathrm{~cm}$ above the sediment-water interface), suggesting that bioirrigation may be a predominant feature of this location. These tubes were possibly constructed by Serbellidae, although no individuals were present in the faunal samples to allow confirmation of species identity.

The faunal cores (Table 2) supported the findings of the SPI, with approximately nine times higher infaunal biomass recorded at the Oyster Ground $\left(177.12 \pm 157.17 \mathrm{~g} \mathrm{~m}^{-2}, n=\right.$ 4) compared with the North Dogger $\left(20.37 \pm 6.93 \mathrm{~g} \mathrm{~m}^{-2}, n\right.$ $=4)$. At the Oyster Ground B. lyrifera was the biomass dominant $\left(84.03 \pm 155.34 \mathrm{~g} \mathrm{~m}^{-2}, n=4\right)$ and Amphiura filiformis the numeric dominant (1124.70 \pm 375.75 individuals $\left.\mathrm{m}^{-2}, n=4\right)$, together accounting for $55.56 \%$ of total biomass. Large bioturbators such as B. lyrifera were absent at the North Dogger where, instead, Nemertea spp. were dominant (4.95 $\left.\pm 6.79 \mathrm{~g} \mathrm{~m}^{-2}, n=4\right)$.
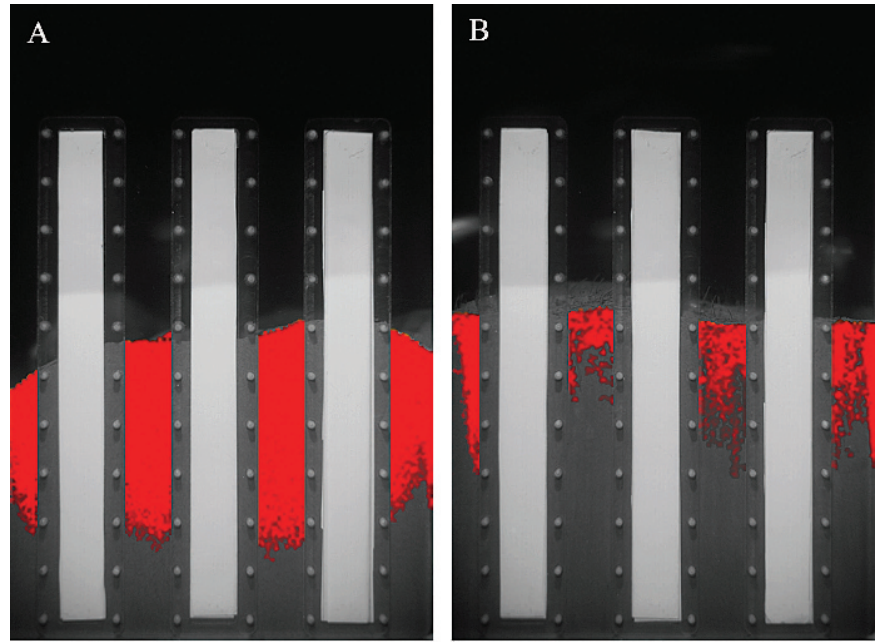

Fig. 1. Representative sediment profile images from (A) the Oyster Ground and (B) the North Dogger in the North Sea. The DGT gel strips (each $20.5 \times 2 \mathrm{~cm}$, gray in color) can be seen in the field of view. The red area in the sediment denotes the more reflective sediment color intensities distinguished by image analysis. Image area $=18 \times 27 \mathrm{~cm}\left(486 \mathrm{~cm}^{2}\right)$.

$\mathrm{Fe}$ and $\mathrm{Mn}$ profiles-Fe and $\mathrm{Mn}$ profiles differed between the two sites, with peaks of both metals tending to occur at shallower sediment depths at the Oyster Ground relative to that of the North Dogger (Fig. 2). The higher variation in $\mathrm{Fe}$ at the Oyster Ground mainly reflected higher values observed in the left-hand-side gel, whereas the central gel showed a deeper point of increase in Mn relative to the other replicates (Fig. 2). At the North Dogger, variability between profiles is less distinct, with peaks recorded at similar depths (Fig. 2). Differences in actual flux values, as opposed to profile shapes, can be attributed to sediment heterogeneity at the millimeter scale; nevertheless both $\mathrm{Fe}$ and Mn fluxes reach marginally higher values at the North Dogger relative to those at the Oyster Ground.

Analysis of Fe flux revealed that six individual smoothers were required (i.e., model M3), indicating that a single smoother model (Eq. M1) is insufficient because of the high variability between profiles. Equation M3 performed better than Eq. M2; thus the within-site variability between replicate profiles is higher than the variability between sites. As model validations showed patterns in the residuals with "depth," we modeled Fe flux using a variance-covariate to allow for unequal variance within depth. The final model revealed significant differences between absolute flux values of $\mathrm{Fe}$ between individual profiles $\left(F_{5}=139.4, p<0.001\right)$, and the six estimated smoothers were highly significant in all cases $(p$ $<0.001)$. The high variability identified between the replicate profiles is visible in the estimated smoothing curves (Fig. 3).

As was the case in the analysis of Fe flux, the GAM fitted to the $\mathrm{Mn}$ profiles also required six individual smoothers and depth as a variance-covariate term. There were significant differences for absolute flux values found between $\mathrm{Mn}$ profiles $\left(F_{5}=131.7, p<0.001\right)$, and the six estimated smoothers were highly significant in all cases $(p$ $<0.001)$. As for Fe, there were no similarities between the six estimated smoothers (Fig. 4), demonstrating the high variability between flux-depth patterns of each profile. 
Table 2. Summary of mean species abundance (abund, $\pm \mathrm{SD}, n=4)$ and biomass $(\mathrm{mg} \pm \mathrm{SD}, n=4)$ per core at the Oyster Ground and North Dogger.

\begin{tabular}{|c|c|c|c|c|c|c|c|c|}
\hline \multirow[b]{2}{*}{ Species } & \multicolumn{4}{|c|}{ Oyster Ground } & \multicolumn{4}{|c|}{ North Dogger } \\
\hline & Abund & $\pm \mathrm{SD}$ & Biomass & $\pm \mathrm{SD}$ & Abund & $\pm \mathrm{SD}$ & Biomass & $\pm \mathrm{SD}$ \\
\hline Abra spp. & 0.25 & 0.50 & 48.25 & 96.50 & - & - & - & - \\
\hline Abyssoninoe spp. & - & - & - & - & 0.50 & 0.58 & 8.08 & 11.13 \\
\hline Ampelisca tenuicornis & 0.25 & 0.50 & 7.00 & 14.00 & 0.25 & 0.50 & 0.03 & 0.05 \\
\hline Amphiura filiformis & 79.50 & 26.56 & 1467.93 & 626.37 & 0.25 & 0.50 & 0.03 & 0.05 \\
\hline Amphiura filiformis (fragments) & 1.00 & 0.00 & 868.75 & 264.21 & - & - & - & - \\
\hline Anaitides rosea & - & - & - & - & 0.25 & 0.50 & 2.23 & 4.45 \\
\hline Brissopsis lyrifera (fragments) & - & - & 5488.80 & 10977.60 & - & - & - & - \\
\hline Callianassa subterranea & 2.00 & 0.82 & 340.50 & 285.49 & 0.25 & 0.50 & 5.33 & 10.65 \\
\hline Ceratocephale lovemi & - & - & - & - & 0.25 & 0.50 & 13.05 & 26.10 \\
\hline Cirratulus cf. caudatus & - & - & - & - & 0.50 & 0.58 & 127.18 & 147.39 \\
\hline Chaetopterus variopedatus & 0.50 & 0.58 & 558.73 & 824.79 & - & - & - & - \\
\hline Corbula gibba & 0.75 & 0.96 & 38.78 & 50.78 & - & - & - & - \\
\hline Cylichna cylindracea & 0.50 & 1.00 & 11.30 & 22.60 & - & - & - & - \\
\hline Diplocirrus glaucus & - & - & - & - & 0.75 & 0.96 & 21.13 & 25.74 \\
\hline Echiurus echiurus (fragments) & - & - & 21.55 & 43.10 & - & - & - & - \\
\hline Echiurus echiurus & 1.00 & 0.82 & 1458.15 & 1646.51 & - & - & - & - \\
\hline Enteropneusta spp. & - & - & - & - & 0.25 & 0.50 & 79.38 & 158.75 \\
\hline Euclymene droebachiensis & - & - & - & - & 0.75 & 0.96 & 46.80 & 54.40 \\
\hline Euclymene droebachiensis (fragments) & - & - & - & - & - & 0.00 & 80.55 & 161.10 \\
\hline Gattyana cirrosa & 0.50 & 0.58 & 38.40 & 59.45 & - & - & - & - \\
\hline Glycera rouxii & - & - & - & - & 0.25 & 0.50 & 7.78 & 15.55 \\
\hline Goniada maculata & - & - & - & - & 0.25 & 0.50 & 4.50 & 9.00 \\
\hline Laonice sarsi & - & - & - & - & 0.50 & 0.58 & 85.58 & 101.64 \\
\hline Leptosynapta decaria & 0.50 & 0.58 & 70.88 & 92.33 & - & - & - & - \\
\hline Magelona alleni & - & - & - & - & 0.25 & 0.50 & 17.70 & 35.40 \\
\hline Malmgreniella andreapolis & 0.25 & 0.50 & 12.58 & 25.15 & - & - & - & - \\
\hline Nemertea spp. & 0.75 & 0.96 & 34.28 & 39.84 & 0.50 & 0.58 & 345.18 & 476.69 \\
\hline Nephtys hombergii & 1.25 & 0.50 & 106.25 & 80.98 & - & - & - & - \\
\hline Nephtys spp. (fragments) & - & - & 32.40 & 41.29 & - & - & 1.85 & 3.70 \\
\hline Notomastus latericeus & 0.50 & 1.00 & 42.03 & 84.05 & 2.00 & 1.15 & 22.35 & 19.85 \\
\hline Notomastus latericeus (fragments) & - & - & 58.68 & 117.35 & - & - & - & - \\
\hline Nuculoma tenuis & - & - & - & - & 0.25 & 0.50 & 2.58 & 5.15 \\
\hline Ophelina acuminata & 1.00 & 1.15 & 49.15 & 71.62 & - & - & - & - \\
\hline Ophiodromus flexuosus & 0.25 & 0.50 & 6.98 & 13.95 & 0.50 & 0.58 & 3.23 & 6.38 \\
\hline Orbinia sertulata & - & - & - & - & 0.25 & 0.50 & 128.70 & 257.40 \\
\hline Owenia fusiformis & 0.25 & 0.50 & 5.63 & 11.25 & - & - & - & - \\
\hline Polychaeta (fragments) & - & - & - & - & 1.00 & 0.00 & 180.45 & 141.28 \\
\hline Pherusa flabellata (fragments) & - & - & 3.53 & 7.05 & - & - & - & - \\
\hline Pherusa flabellata & 0.50 & 1.00 & 39.18 & 78.35 & - & - & - & - \\
\hline Praxillella spp. & - & - & - & - & 0.25 & 0.50 & 1.80 & 3.60 \\
\hline Rhodine gracilior & - & - & - & - & 0.25 & 0.50 & 22.88 & 45.75 \\
\hline Saxicavella jeffreysi & 1.75 & 2.22 & 71.43 & 79.28 & - & - & - & - \\
\hline Scalibregma inflatum & 0.25 & 0.50 & 3.60 & 7.20 & - & - & - & - \\
\hline Scolelepis cf. korsuni & - & - & - & - & 0.75 & 0.50 & 12.48 & 9.54 \\
\hline Scoloplos armiger & - & - & - & - & 0.25 & 0.50 & 7.23 & 14.45 \\
\hline Spiophanes kroyeri & - & - & - & - & 0.25 & 0.50 & 11.85 & 23.70 \\
\hline Streblosoma bairdi & - & - & - & - & 0.25 & 0.50 & 169.68 & 339.35 \\
\hline Turritella communis & 0.75 & 0.96 & 1105.38 & 1323.90 & - & - & - & - \\
\hline Thyasira spp. & - & - & - & - & 1.50 & 1.29 & 12.33 & 13.54 \\
\hline Upogebia stellata & 0.75 & 0.96 & 530.43 & 792.97 & - & - & - & - \\
\hline Virgularia mirabilis & - & - & - & - & 0.25 & 0.50 & 22.33 & 44.65 \\
\hline
\end{tabular}

Segmented regressions on the Fe-Mn relationships showed significant break points $(p<0.01)$ in all cases and revealed clear differences between the Oyster Ground and the North Dogger. The mean depth $( \pm \mathrm{SD})$ of the break point was more variable at the Oyster Ground $(7.7 \pm$ $4.0 \mathrm{~cm}, n=3)$ than it was at the North Dogger $(10.2 \pm$
$1.0 \mathrm{~cm}, n=3$ ). Regression lines fitted to the mean fluxes at each station (Fig. 5) summarize this variability, with the higher variability of points around the regression lines observed at the Oyster Ground and the closer association of points with the regression lines observed at North Dogger. The difference in slopes before and after the break 

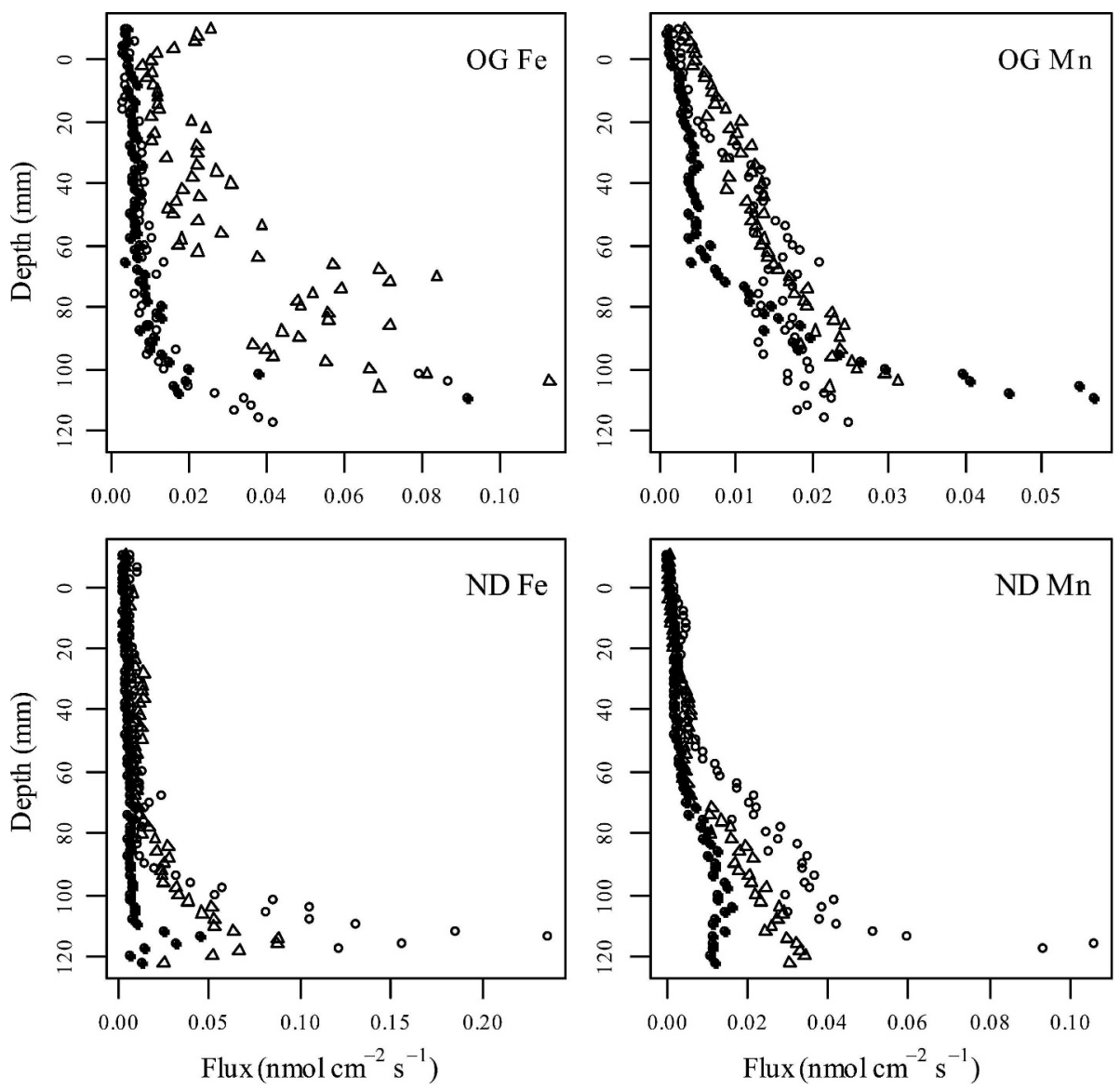

Fig. 2. The flux of Fe and Mn to the DGT gel strips on the g-SPI at the Oyster Ground (OG) and North Dogger (ND). Symbols correspond to the position of the gel on the faceplate (left, triangle; center, full circle; right, open circle).

point is less at the Oyster Ground $\left(\beta_{1}=1.041 ; \beta_{2}=0.3747\right)$ than at North Dogger $\left(\beta_{1}=1.802 ; \beta_{2}=0.133\right)$. When taken with the higher variability in the depth of the break point, these data indicate that a spatially more complex redox environment exists at the Oyster Ground.

The mean depths $( \pm \mathrm{SD})$ of the Fe-Mn break points at the Oyster Ground ( $7.7 \pm 4.0 \mathrm{~cm}, n=3)$ are consistent with the mean $( \pm \mathrm{SD})$ color transition depth determined from the sediment profile images $(4.78 \pm 0.76 \mathrm{~cm}, n=4)$. Indeed, the very gradual color change and less distinct color transition depth found at this station are consistent with expectations given the variability in points around both the regression lines and the break points. At the North Dogger, however, both color transition depth and the FeMn break points show less variability, indicating more distinct horizontal layering of redox processes in the sediment. Nevertheless, a large discrepancy between the depth of the color transition $(2.86 \pm 0.78 \mathrm{~cm})$ and the FeMn break points $(10.2 \pm 1.0 \mathrm{~cm})$ is evident.

\section{Discussion}

By combining two in situ technologies, we were able to link vertical sediment color transitions to geochemical (metal) profiles at high spatial (SPI and DGT) and temporal (SPI) resolution and observe how these relationships are modified by infaunal activity at two ecologically contrasting stations in the North Sea. It is clear that differences between the depth of vertical color transition and the $\mathrm{Fe}$ redox boundary, as derived from pore-water metal profiles, are likely a common feature when comparing within- or between-station replicates, but that such differences do not necessarily translate to fundamental differences in bulk chemistry. Previous studies (Lyle 1983; König et al. 1997; Bull and Williamson 2001) linking sediment color to the presence of $\mathrm{Fe}$, however, have demonstrated that insoluble $\mathrm{Fe}$ oxides in an oxidizing environment give the sediment a tan-brown coloration. A semiquantitative relationship between overall color of sediments and associated concentrations of $\mathrm{FeOOH}$ and acid volatile sulfides (AVS) has also been demonstrated (Williamson et al. 1999). Lyle (1983) hypothesized that the change in color with depth is likely caused by the reduction of $\mathrm{Fe}(\mathrm{III})$ to $\mathrm{Fe}(\mathrm{II})$ in smectite lattices, a finding later corroborated by others (König et al. 1997); a significant downcore shift in the sediment $\mathrm{Fe}$ (III) : $\mathrm{Fe}$ (II) ratio occurs toward higher values at the boundary of the tan-green color transition. These studies, however, focused on the solid phases of $\mathrm{Fe}(\mathrm{III})$ and $\mathrm{Fe}(\mathrm{II})$ and did not consider the reduced soluble $\mathrm{Fe}$ forms in the pore waters. Here, the 

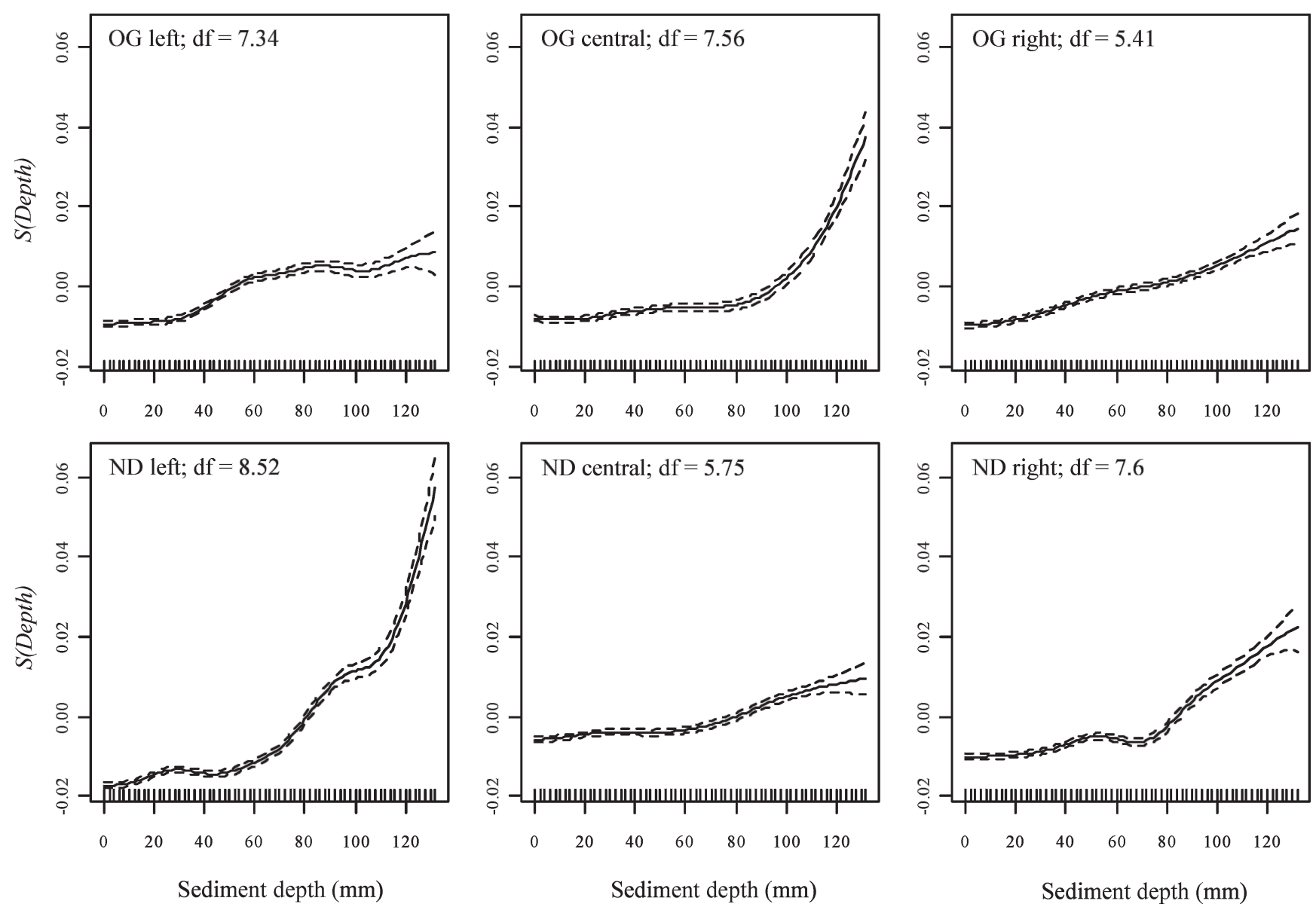

Fig. 3. GAM-fitted smoother values of Fe flux with depth. Smoothers (solid lines) $\pm 95 \% \mathrm{CI}$ (dotted lines) are presented for left, central, and right gels at the Oyster Ground (OG) and North Dogger (ND). The distribution of individual pore-water measurements is indicated by the inward ticks on the $x$-axis. Degrees of freedom (df) for the smoother used is shown on each panel.

results obtained at the Oyster Ground show that the soluble Fe measured by the DGT appears at the depth of the color change, linking these processes together as predicted (Lyle 1983; König et al. 1997). For the discrepancy between the color change and the depth of Fe peak at the North Dogger, it is clear that other processes are occurring that are affecting the availability of the reduced and soluble Fe to the DGT.

As sulfide minerals are important carriers of many trace metals, sulfide production plays an important role in the cycling of $\mathrm{Fe}$ in marine sediments. In anoxic or mixed redox sediments, where pyrite $\left(\mathrm{FeS}_{2}\right)$ is the dominant form of solid-phase sulfur, dissolved sulfur reacts with iron oxides, or $\mathrm{Fe}^{2+}$, to form iron monosulfides (FeS) and pyrite $\left(\mathrm{FeS}_{2}\right)$. Although sulfate reduction is not important in mid-ocean sediments, it is the predominant process by which organic matter undergoes remineralization processes in coastal and continental margin sediments and uptake of metals into AVS occurs more frequently (Reeburgh 1983). Manganeseand iron-reducing bacteria outcompete sulfate reduction when sufficiently reactive metal oxides are present (King 1990) and a vertical sequence, although not necessarily sharply defined, of $\mathrm{Mn}, \mathrm{Fe}$, and sulfate reduction likely occurs below the oxic and denitrification zones (Sørensen and Jørgensen 1987; Canfield et al. 1992). It can therefore be hypothesized that in the presence of sulfate reduction, following reduction of $\mathrm{Fe}$ (III) to $\mathrm{Fe}$ (II) at the tan-green color boundary, reduced soluble $\mathrm{Fe}^{2+}$ is bound into iron monosulfides $(\mathrm{FeS})$ or pyrite $\left(\mathrm{FeS}_{2}\right)$ instead of being released into the pore waters. These two forms of $\mathrm{Fe}$ are not available to the DGT technique.

Sulfate reduction rates measured at the same locations over the same time period support this hypothesis (Fig. 6). Although measurements were not taken at as high resolution as the present study and the actual peak rates may therefore have been missed, the profiles indicate higher rates of sulfate reduction at the shallower sediment depths $(0-7 \mathrm{~cm})$ at the North Dogger relative to the Oyster Ground. Peak rates of sulfate reduction at the North Dogger occur around the depth of the color boundary and the lack of Fe peaks in the DGT profiles at this depth is therefore most likely due to complexation of $\mathrm{Fe}$ to $\mathrm{FeS}$. Metals bind to the chelex resin gel in the DGT through donation of an electron (Davison et al. 2000) and as the gels accumulate cations, only soluble forms of $\mathrm{Fe}$ (i.e., not iron monosulfides $[\mathrm{FeS}]$ ) will be available to the DGT method. Lower rates of sulfate reduction at the Oyster Ground indicate that complexation of $\mathrm{Fe}$ to $\mathrm{FeS}$ is less likely to 

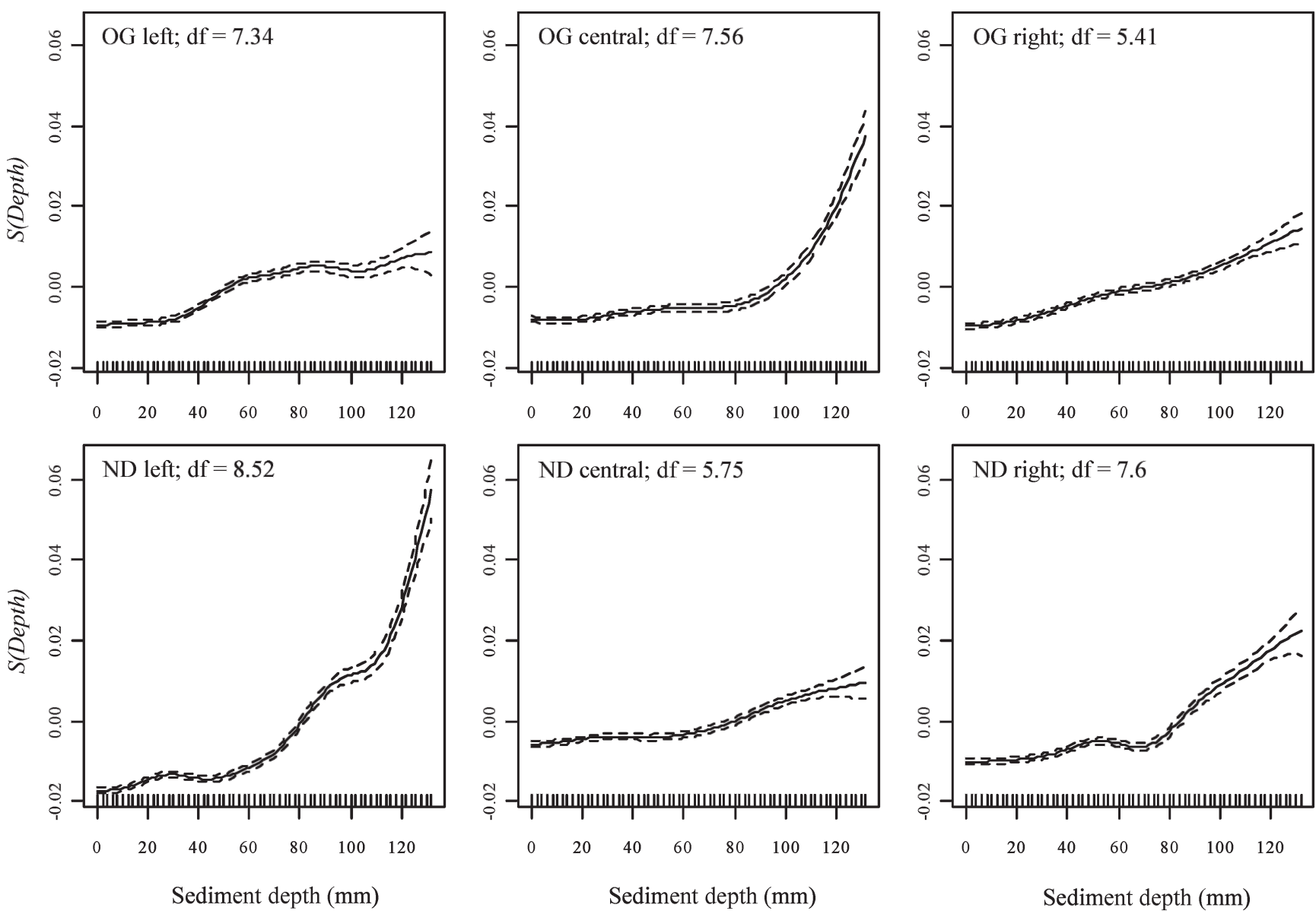

Fig. 4. GAM-fitted smoother values of Mn flux with depth. Smoothers (solid lines) $\pm 95 \%$ CI (dotted lines) are presented for left, central, and right gels at the Oyster Ground (OG) and North Dogger (ND). The distribution of individual pore-water measurements is indicated by the inward ticks on the $x$-axis. Degrees of freedom (df) for the smoother used is shown on each panel.

predominate within the observed depths at this station; hence the color and DGT profile results correspond to one other. Consequently it can be concluded that the color boundary measured by SPI is consistently showing the boundary where reductive dissolution of $\mathrm{Fe}$ occurs $(\mathrm{Fe}$ redox boundary), whereas DGT is measuring the availability of soluble Fe in the pore waters. Possible complexation of $\mathrm{Fe}$ in the presence of high sulfate reduction rates rules

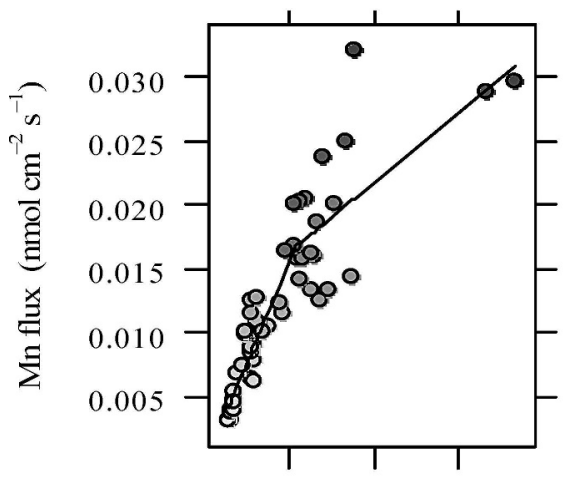

$0.02 \quad 0.04 \quad 0.06$

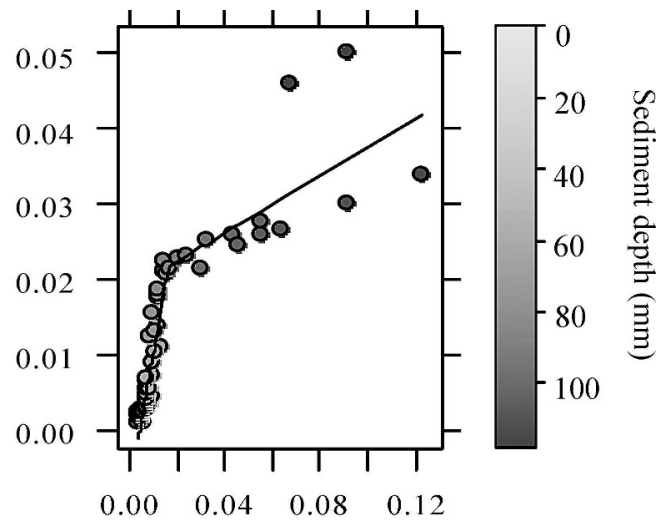

Fe flux (nmol cm $\left.{ }^{-2} \mathrm{~s}^{-1}\right)$

Fe flux (nmol cm $\left.\mathrm{cm}^{-2} \mathrm{~s}^{-1}\right)$

Fig. 5. The relationship between mean $(n=3) \mathrm{Fe}$ and mean $(n=3) \mathrm{Mn}$ flux with sediment profile depth (mm, indicated by gray shading) at the Oyster Ground (OG) and North Dogger (ND). Lines represent segmented regression and the flex indicates the position of the break point. 


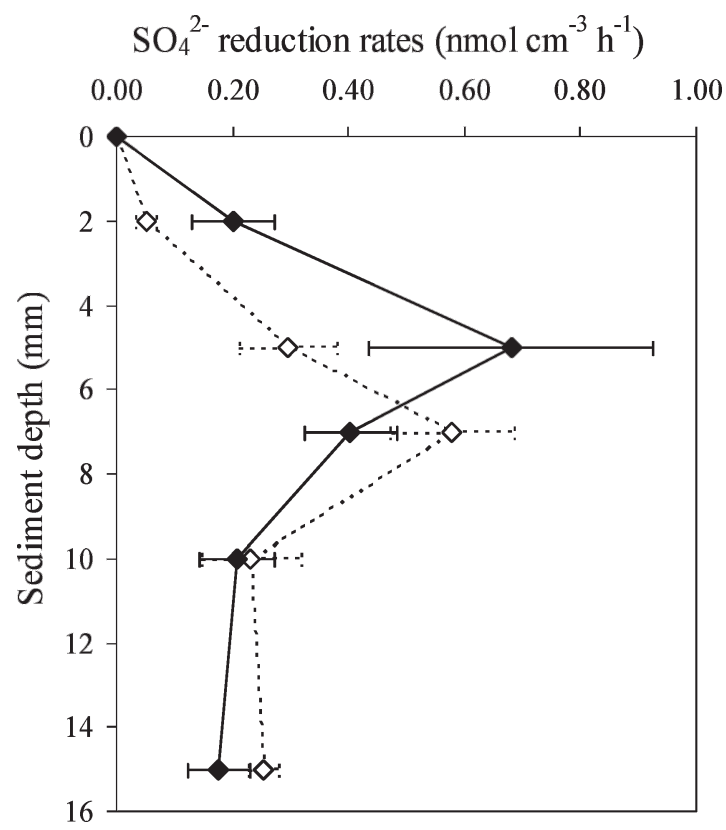

Fig. 6. Sulfate reduction rates $\left(\mathrm{nmol} \mathrm{cm}^{-3} \mathrm{~h}^{-1}\right)$ within the sediment at the Oyster Ground (dotted line, open diamonds) and North Dogger (solid line, closed diamonds). Individual points denote actual measurements with standard error bars $(n=3)$. Unpublished data received from E. Neubacher, Queens University London.

out a straightforward interpretation of biogeochemical zonation patterns from DGT profiles and inferring $\mathrm{Fe}$ redox zonation from such profiles could lead to overestimation of the depth at which the boundary occurs (as is the case at the North Dogger).

Interpretation of $\mathrm{Fe}$ and $\mathrm{Mn}$ profiles often, however, ignores the activity of bioturbating invertebrates. At the North Dogger, the infaunal community is characterized by low abundances, low biomass, a species-poor community, and the time-lapse sequence shows no evidence of any major bioturbation events. Less faunal activity decreases the mixing depth of the sediment, resulting in a shallow color transition (Fe redox boundary) and a very distinct biogeochemical zonation pattern, i.e., the biogeochemical reaction layers are not perturbed by infaunal activity and microbial processes are likely to be dominating. The comparatively species-rich community of the Oyster Ground, however, is dominated by large bioturbators such as B. lyrifera and A. filiformis that are known to be active bioturbators and capable of rapidly transporting large amounts of sediment particles as well as positively affecting the transport of fluids within the sediment pore waters (Solan and Kennedy 2002; Lohrer et al. 2004). Such activity complicates any biogeochemical zonation through the creation of complex three-dimensional mosaics of biogenic microenvironments and spatially heterogeneous redox conditions (Forster and Graf 1992; Aller 1994). Indeed, the high variability observed in the points around the segmented regression line, and the variability of the depth of the Fe-Mn break point $(4-11 \mathrm{~cm})$, as well as the gradual, indistinct color change in the sediment at the Oyster Ground contrast with a very distinct color change, restricted depth range of the $\mathrm{Fe}-\mathrm{Mn}$ break point $(9-11 \mathrm{~cm})$, and a tighter fit of points around the segmented regression lines at North Dogger. Whereas at the Oyster Ground faunal activity has a greater influence over trace metal profiles relative to sulfate reduction, the evidence suggests that the reverse is the case at the North Dogger because of the presence of a comparatively depauperate invertebrate community.

Collectively, our study has demonstrated that the color transition observed in the sediment profile reflects the depth to which Fe remains insoluble (Fe redox boundary), whereas profiles derived using DGT reveal the depth at which trace metals become available in the pore waters without being linked specifically to a redox boundary. Although it is clear that higher replication is necessary to reliably detect intersite differences in trace metal profiles, the simultaneous use of two established techniques adopted here has allowed observations to be interpreted in light of recent biological activity. This has important implications because our understanding of the dynamics of benthic biogeochemistry can only be fully understood if we adopt a holistic and integrated approach to routine monitoring, coastal management, and conservation.

\section{Acknowledgments}

We thank the crew and scientists of the RV Endeavour (Centre for Environment, Fisheries and Aquaculture Science [CEFAS], cruise END10/07), O. McPherson and A. Holford for helping with the transport of the sediment profile imaging camera between Aberdeen and Lowestoft, A. Jamieson and P. Bagley for design of the DGT faceplate, and S. Tierney for assistance with the inductively coupled plasma-mass spectrometer. We are grateful to E. Neubacher for allowing us to use her data on sulfate reduction rates and to S. Apitz, S. Eriksson, P. Hall, and two anonymous reviewers for useful comments on earlier versions of the manuscript.

Jointly supported by a University of Aberdeen 6th-century scholarship (awarded to L.R.T.) and CEFAS, Lowestoft (DP204), with additional support from the National Environment Research Council (Connect A grant NE/F523285/1, awarded to G.F.). Funding of ship time was obtained through Defra Marine Ecosystem Connections (E3205).

\section{References}

Aller, R. C. 1982. The effects of macrobenthos on chemical properties of marine sediments and overlying water, p. 53102. In P. L. Call and M. J. S. Tevesz [eds.], Animal-sediment relations, the biogenic alteration of sediments. Plenum.

. 1994. Bioturbation and remineralisation of sedimentary organic matter: Effects of redox oscillation. Chem. Geol. 114: 331-345.

Bull, D. C., and R. B. Williamson. 2001. Prediction of principal metal-binding solid phases in estuarine sediments from color image analysis. Environ. Sci. Technol. 35: 1658-1662.

Burdige, D. J., S. P. Dhakar, and K. H. Nealson. 1992. Effects of manganese oxide mineralogy on microbial and chemical manganese reduction. Geomicrobiol. J. 10: 27-48.

Canfield, D. E., R. Raiswell, and S. Bottrell. 1992. The reactivity of sedimentary iron minerals toward sulfide. Am. J. Sci. 292: 659-683.

Ciceri, G., S. Maran, W. Martinotti, and G. Queirazza. 1992. Geochemical cycling of heavy metals in a marine coastal areabenthic flux determination from porewater profiles and in situ measurements using benthic chambers. Hydrobiologia 235: 501-517. 
Davison, W., G. R. Fones, M. Harper, P. Teasdale, and H. Zhang. 2000. Dialysis, DET, and DGT: In situ diffusional techniques for studying water, sediments, and soils, p. 496569. In J. Buffle and G. Horvai [eds.], In-situ monitoring of aquatic systems: Chemical analysis and speciation. IUPAC. Wiley.

Diaz, R. J., AND G. R. Cutter. 2001. In situ measurement of organism-sediment interaction: Rates of burrow formation/ abandonment and sediment oxidation/reduction, p. 19-32. In J. Y. Aller, S. A. Woodin and R. E. Aller [eds.], Animalsediment interactions. Univ. of South Carolina Press.

-, AND J. H. Trefry. 2006. Comparison of sediment profile image data with profiles of oxygen and Eh from sediment cores. J. Mar. Systems. 62: 164-172.

Fenchel, T. 1969. The ecology of marine microbenthos. IV. Structure and function of the benthic ecosystem, its chemical and physical factors and microfauna communities with special reference to the ciliated Protozoa. Ophelia 6: 1-182.

Fones, G. R., W. Davison, and J. Hamilton-Taylor. 2004. The fine-scale remobilization of metals in the surface sediment of the North-East Atlantic. Cont. Shelf. Res. 24: 1485-1504.

Forster, S., AND G. Graf. 1992. Continuously measured changes in redox potential influenced by oxygen penetrating from burrow of Callianassa subterranea. Hydrobiologia 235/236: 527-532.

Grizzle, R. E., and C. A. Penniman. 1991. Effects of organic enrichment on estuarine macrofaunal benthos - a comparison of sediment profile imaging and traditional methods. Mar. Ecol. Prog. Ser. 74: 249-262.

Johnson, K. S., F. P. Chavez, and G. E. Friedriech. 1999. Continental-shelf sediment as a primary source of iron for coastal phytoplankton. Nature 398: 697-700.

Jørgensen, B. B. 1983. Processes at the sediment-water interface, p. 477-509. In B. Bolin and R. C. Cook [eds.], The major biogeochemical cycles and their interactions. SCOPE.

Josefson, A. B., T. L. Forbes, And R. Rosenberg. 2002. Fate of phytodetritus in marine sediments: Functional importance of macrofaunal community. Mar. Ecol. Prog. Ser. 230: 71-85.

KING, G. M. 1990. Effects of added manganic and ferric oxides on sulfate reduction and sulfide oxidation in intertidal sediments. FEMS Microbiol. Ecol. 72: 131-138.

König, I., M. Drodt, E. Suess, and A. X. Trautwein. 1997. Iron reduction though the tan-green color transition in deep-sea sediments. Geochim. Cosmochim. Acta. 61: 1679-1683.

LAST, K. S. 2003. An actograph and its use in the study of foraging behaviour in the benthic polychaete, Nereis virens Sars. J. Exp. Mar. Biol. Ecol. 287: 237-248.

Lesven, L., Y. Gao, G. Billon, M. Leermakers, B. Ouddane, J. C. FisCher, AND W. BAEYENS. 2008. Early diagenetic processes aspects controlling the mobility of dissolved trace metals in three riverine sediment columns. Sci. Tot. Environ. 407: 447-459.

Lohrer, A. M., S. F. Thrush, And M. M. Gibbs. 2004. Bioturbators enhance ecosystem function through complex biogeochemical interactions. Nature 431: 1092-1095.

Lyle, M. 1983. The brown-green color transition in marine sediments: A marker of the Fe(III)-Fe(II) redox boundary. Limnol. Oceanogr. 28: 1026-1033.

Muggeo, V. M. R. 2003a Estimating regression models with unknown break-points. Stat. Med. 22: 3055-3071.

. 2003b. Segmented: An R package to fit regression models with broken-line relationships. Available at: www.stats.bris. ac.uk/R/

Pinheiro, J. C., And D. M. Bates. 2000. Mixed-effects models in S and S-Plus. Springer.
, D. M. Bates, S. Debroy, and D. Sarkar. 2006. nlme: An $\mathrm{R}$ package for fitting and comparing Gaussian linear and nonlinear mixed-effects models. Available at: www.stats.bris. ac.uk/R/

Reeburgh, W. S. 1983. Rates of biogeochemical processes in anoxic sediments. Ann. Rev. Earth Planet. Sci. 11: 269-298.

Rhoads, D. C., And S. CAnde. 1971. Sediment profile imaging camera for in-situ study of organism-sediment interactions. Limnol. Oceanogr. 16: 110-114.

—, AND J. D. Germano. 1982. Characterization of organismsediment relations using sediment profile imaging: An efficient method of remote ecological monitoring of the seafloor (REMOTS system). Mar. Ecol. Prog. Ser. 8: $115-128$.

Rosenberg, R., H. C. Nilsson, And R. J. Diaz. 2001. Response of benthic fauna and changing sediments redox profiles over a hypoxic gradient. Estuar. Coast. Shelf Sci. 53: 343-350.

Shchukarev, A., V. Gälman, J. Rydberg, S. Sjöberg, and I. RENBERG. 2007. Speciation of iron and sulphur in seasonal layers of varved lake sediment: An XPS study. Surf. Interface Anal. 40: 354-357.

Solan, M., AND R. KenNedy. 2002. Observation and quantification of in-situ animal-sediment relations using time-lapse sediment profile imagery (t-SPI). Mar. Ecol. Prog. Ser. 228: 179-191.

, B. D. Wigham, I. R. Hudson, R. Kennedy, C. H. Coulon, K. Norling, and R. Rosenberg. 2004. In-situ quantification of bioturbation using time-lapse fluorescent sediment profile imaging (f-SPI), luminophore tracers and model simulation. Mar. Ecol. Prog. Ser. 271: 1-12.

Sørensen, J., AND B. B. Jørgensen. 1987. Early diagenesis in sediments from Danish coastal waters: Microbial activity and Mn-Fe-S geochemistry. Geochim. Cosmochim. Acta 51: 1583-1590.

Teal, L. R., M. T. Bulling, E. R. Parker, and M. Solan. 2008. Global patterns of bioturbation intensity and mixed depth of marine soft sediment. Aquat. Biol. 2: 207-218.

Thamdrup, B., H. Fossik, And B. B. Jørgensen. 1994. Manganese, iron, and sulfur cycling in a coastal marine sediment, Aarhus Bay, Denmark. Geochim. Cosmochim. Acta 58: 5115-5129.

Williamson, R. B., R. J. Wilcock, B. E. Wise, and S. E. Pickmere. 1999. Effect of burrowing by the crab Helice crassa on chemistry of intertidal muddy sediments. Environ. Toxicol. Chem. 18: 2078-2986.

Witte, U., AND others. 2003. In situ experimental evidence of the fate of a phytodetritues pulse at the abyssal sea floor. Nature 424: 763-766.

Wood, S. N. 2006. Generalised additive modelling: An introduction. R. Chapman and Hall.

2009. mgcv: An R package with routines for GAMs and other generalized ridge regression with multiple smoothing parameter selection by GCV or UBRE/AIC. Also GAMMs by REML. Available at: www.stats.bris.ac.uk/R/

Zhang, H., W. Davison, S. Miller, and W. Tych. 1995. In situ high-resolution measurements of fluxes of $\mathrm{Ni}, \mathrm{Cu}, \mathrm{Fe}$, and $\mathrm{Mn}$ and concentrations of $\mathrm{Zn}$ and $\mathrm{Cd}$ in porewaters by DGT. Geochim. Cosmochim. Acta 59: 4181-4192.

Associate editor: Markus H. Huettel

Received: 13 March 2009

Accepted: 19 May 2009

Amended: 03 June 2009 